EPiC Series in Engineering
Volume 3, 2018, Pages 1078-1080
HIC 2018. 13th International
Conference on Hydroinformatics

\title{
Evaluation of Low Impact Development using EPA SWMM-LID Modeling
}

\author{
Jungho $\mathrm{Kim}^{1}$ and Jungul $\mathrm{Joo}^{2 *}$ \\ ${ }^{1}$ College of Engineering, Colorado State University, Colorado State, USA \\ ${ }^{2}$ Department of Civil Engineering, Dongshin University, Naju-si, Jeollanam-do, Korea \\ bbanz2@hanmail.net, jgjoo@dsu.ac.kr
}

\begin{abstract}
This study implemented the evaluation of Low Impact Development (LID) using SWMM-LID model developed by the U. S. Environmental Protection Agency (EPA), to assess the quantitative performance of LID facilities (seven type of LID facilities installed, vegetation place, plants garden pot, tree filter box, permeable pavement, infiltration ditch, rain barrel, infiltration rain-block). SWMM-LID modeling was useful to reflect the LID design into the model using the technical content representing LID facility in SWMM-LID. In the event-based result, the stormwater reduction was considerable since the reduction in average was $76.6 \%$ by the LID facilities. In the longterm result, the range of the reduction in average was $11.5 \sim 77.7 \%$ for seven types of LID facilities, and the average reduction for the total drainage area was $22.9 \%$. The monthly reduction rate was affected by total rainfall depth and rainfall intensity.
\end{abstract}

\section{Introduction}

The developed countries are faced with the necessity of the Low Impact Development (LID) since it is very useful and efficient in urban area. LID technique can reduce the natural hazard by decreasing the direct runoff, can improve the unnatural water cycle due to impervious area, and can be applied for the rainfall water recycle and the pollution management. Also, LID technique facility adapts the ecofriendly design which can reflect the natural water cycle function on the ground and under the ground (Dietz, 2007; Ahiablame et al. 2012; Kim et al., 2017). However, the case study to access the effect of LID on the stormwater reduction is still needed.

This study implements the evaluation of the LID facility's performance using SWMM-LID modeling. For this purpose, this study applies seven types of LID facilities. SWMM-LID modeling is implemented based on the LID design plan to reflect the actual features into the SWMM-LID model.

${ }^{*}$ Created the first draft of this document 
The model is calibrated using the observed monitoring data (before and after LID installation). Chungju industrial complex in South Korea is applied as the test-bed having seven types of LID facilities such as vegetation place, plants garden pot, tree filter box, permeable pavement, infiltration ditch, rain barrel, infiltration rain-block. The evaluation is consisted of the short/long-term and LID facility-based and the subbasin-based.

\section{EPA SWMM-LID Module}

SWMM-LID provides eight types of LID technical contents which can represent LID facilities, and the technical contents consist of surface, soil and storage layers. Each layer is designed to reflect the LID facility design plan, so that the actual size of LID facility can be applied as the LID technical contents parameters in SWMM-LID (Abi Aad et al., 2009; EPA, 2015). This study matched the actual facility with SWMM-LID technical content to reflect the LID functions such as infiltration, filter, storage and etc. (Table 1). This process is implemented considering the actual LID design.

\begin{tabular}{|c|c|c|c|c|c|c|}
\hline $\begin{array}{r}\text { SWMM } \\
\text { contents }\end{array}$ & $\begin{array}{c}\text { Bio- } \\
\text { Retention } \\
\text { Cell }\end{array}$ & $\begin{array}{c}\text { Rain } \\
\text { Garden }\end{array}$ & $\begin{array}{c}\text { Infiltration } \\
\text { Trench }\end{array}$ & $\begin{array}{c}\text { Permeable } \\
\text { Pavement }\end{array}$ & $\begin{array}{c}\text { Rain } \\
\text { Barrel }\end{array}$ & $\begin{array}{c}\text { Vegetative } \\
\text { Swale }\end{array}$ \\
\hline Vegetation place & 0 & & & & & \\
\hline Plants garden pot & 0 & O & & & & O \\
\hline Infiltration rain-block & & & 0 & & 0 & \\
\hline Rain barrel & & & O & & 0 & \\
\hline Infiltration ditch & & & ( & & & \\
\hline Filtering tree box & O & & ( & & & \\
\hline Permeable pavement & & & & $(0$ & & \\
\hline
\end{tabular}

Table 1: The selected SWMM-LID technical contents corresponding to the installed LID facilities

\section{Modeling and Results}

The calibration is implemented using the observed monitoring data from 2014 (before LID installation) to 2015 (after LID installation) year. For the event-based evaluation, this study used four storm events in 2016. The reduction is calculated using the equation (1) as below.

$$
\operatorname{Re} \operatorname{duction}(\%)=\frac{\left(Q_{\text {NoLLD }}-Q_{L I D}\right)}{Q_{\text {NoLID }}} \times 100(\%)
$$

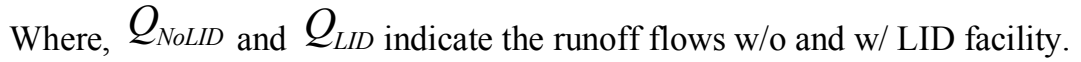

In the event-based evaluation, the results showed that tree filter box $90.1 \%$, rain barrel $33.9 \%$, plants garden pot $100.0 \%$, infiltration rain-block $51.1 \%$, vegetation place $88.1 \%$, infiltration ditch $100.0 \%$, permeable pavement $69.9 \%$. Annual average reductions for 11 years (2005 2015) long-term simulation 
are tree filter box $73.0 \%$, rain barrel $11.5 \%$, plants garden pot $77.7 \%$, infiltration rain-block $37.7 \%$, vegetation place $39.8 \%$, infiltration ditch $66.8 \%$, permeable pavement $38.6 \%$. The average reduction of LID facilities for 11 years is $48.4 \%$. Depending on the fluctuation of precipitation, the infiltration ditch showed the stable performance, but rain barrel was most affected.

This study found that the reduction (14.6\%) during the wet season (Jun. - Sep.) is relatively lower, and the reduction (31.7\%) during the dry season (Jan., Feb., Nov., and Dec.) is roughly two times higher than the wet season.

\section{Conclusions}

This study implemented the evaluation of the LID performance using SWMM-LID modeling with seven types of LID facilities installed the industrial complex, South Korea. The modeling was applied for a period from 2005 to 2015. In 11 years long-term modeling, the range of average reduction was $11.5 \sim 77.7 \%$ depending on the type of LID facility. According to the result from the monthly stormwater reduction, the reduction during rainy season was relatively lower and the reduction during dry season was higher due to the fluctuation of precipitation. In the future, the study to access the effect of rainfall intensity on the LID performance is needed.

\section{References}

Abi Aad, Maya P., Makram T. Suidan, and William D. Shuster, Modeling techniques of best management practices: Rain barrels and rain gardens using EPA SWMM-5. Journal of Hydrologic Engineering 15(6), (2009) 434-443.

Ahiablame, L.M., Engel, B.A. \& Chaubey, I., Effectiveness of low impact development practices: literature review and suggestions for future research. Water Air Soil Pollut, 223(7), (2012) 4253-4273.

Dietz, M. E., Low impact development practices: a review of current research and recommendations for future directions. Water, air, and soil pollution, 186(1-4), (2007) 351-363. $1-353$.

Environmental Protection Agency, Storm water management model user's manual version 5.1. 2015

Kim, J., Choi, S., and Joo, J., EPA SWMM-LID modeling for low impact development. Journal of Korean Society and Water Quality, 17(2), (2017) 415-424.

\section{Acknowledgement}

This research was supported by a grant 'Development of the Evaluation Technology for Complex Causes of Inundation Vulnerability and the Response Plans in Coastal Urban Areas for Adaptation to Climate Change' [MPSS-NH-2015-77] from the Natural Hazard Mitigation Research Group, Ministry of Public Safety and Security of Korea. 